ljtihad: Jurnal Wacana Hukum Islam dan Kemanusiaan

Vol. 20, No. 1 (2020), pp. 61-78, doi : 10.18326/ijtihad.v20i1.61-78

\title{
Cigarette fatwas, contestation of religious authority and politics in Indonesia
}

\author{
Saifuddin \\ Institut Agama Islam Negeri (LAIN) Kudus \\ E-mail: saifuddin.zubaidi@yahoo.com \\ DOI: 10.18326/ijtibad.v20i1.61-78
}

The issuance of non-binding advisory opinions ( $f a t w a)$ is always followed by the presence of new issues related to the implementation of the fatwa. Similarly, the smoking ruling was issued by the Council of Indonesian Scholars (MUI) at the Conference in Padang Panjang in 2009. More than a decade this subject is still debatable. Although the fatwa in Indonesia does not have the power of binding, for Muslims, the idea of religious morality remains a consideration in daily life. Through a literature study, this study will reveal how the problematic relations between various social agencies regarding the issuance of the cigarette fatwa. Discourse debates in the study of fiqh will begin the explanation of this study, followed by development policies in Indonesia related to the problem of cigarettes, and ended with the position of the ulema as the holder of religious authority in the matter of smoking. This study illustrates that the practice of fatwas will be effective when ulama as religious authority holders, with their "capital", can negotiate and contest with various social agents in the cigarette fatwa arena.

Keluarnya fatwa hukum selalu diikuti oleh hadirnya persoalan baru terkait dengan pelaksanaan fatwa tersebut. Begitu juga fatwa rokok yang dikeluarkan oleh Majlis Ulama Indonesia dalam sidang ijtima'Ulama di Padang Panjang tahun 2009 silam. Lebih dari satu dekade perdebatan mengenai hal ini masih menjadi polemik di masyarakat. Meskipun fatwa di Indonesia tidak mempunyai kekuatan mengikat, tetapi bagi ummat muslim bayangan tentang moral agama tetap menjadi pertimbangan dalam menjalani kehidupan sehari-hari. Melalui studi literatur, kajian ini akan mengungkap bagaimana problematika relasi antar berbagai agen sosial terkait dengan keluarnya fatwa rokok tersebut. Perdebatan wacana dalam kajian fiqih akan mengawali penjelasan kajian ini, disusul dengan kebijakan pembangunan di Indonesia terkait dengan problematika rokok, dan diakhiri dengan poisisi ulama sebagai pemegang otoritas keagamaan dalam masalah rokok. Kajian ini memberikan 
Ijtihad: Jurnal Wacana Hukum Islam dan Kemanusiaan, Volume 20, No. 1, Juni 2020: 61-78

gambaran bahwa praktik fatwa akan efektif ketika ulama sebagai pemegang otoritas keagamaan, dengan "modal" yang mereka miliki, mampu bernegosiasi dan berkontestasi dengan berbagai agen sosial dalam arena fatwa rokok.

Keyword: Fatwa Cigarette; Capital; Fatwa Practice; Ulama

\section{Introduction}

Since being issued of the fatwa on smoking by the Indonesian Council of Ulama (MUI) in 2009, the practice of smoking especially in Indonesia as a Muslim-majority country has been a debatable topic for discussion. No half-hearted, the issue of smoking has entered the area of economic, political, and debate in culture and religion. There are at least three important issues related to cigarette fatwa and smoking practice problems in the Indonesian Muslim community. The most important issue to be discussed is the long-standing cigarette fatwa discourse among salaf scholars, and these debates are reflected in some classical and modern figh literature.

The Islamic movement (Islamism) in Indonesia also took part in the practice of cigarette fatwa. The moderate to a radical character in the Islamic movement establish to the degree of issuing fatwa mubah to haram against cigarettes. A crucial issue in the practice of cigarette fatwa is how political forces participate in taking a role in the form of policies and laws so that the contents of fatwas become binding forces. The contestation of various social agents about the fatwa of cigarettes is increasingly attracting attention because it takes place on the foundation of the smoking culture of the Muslim community that has been established since the Republic of Indonesia was not yet born.

The viscosity of smoking culture among Indonesian people is reflected in the expression of Pamoedya Ananta Tour in an introduction in the book 'Kretek, The Culture and Heritage of Indonesia's Clove Cigarettes', “people smoke, because they feel that there is something missing when they do not, so too when cigarettes are not seasoned with cloves, something is missing and tasteless " (Hanusz, 2011: XVI). Pramoedya Ananta Toer's words quote shows that smoking is an important part of Indonesian people's lives, because smoking is a taste, and the taste is an important element of culture. Like taste, according to Pram, clove cigarettes will make life bland. 
Cigarettes as a part of culture have a history as well as social functions such as the function of togetherness and rite (Hanusz, 2011), colouring the world of science and politics (Brandt, 2007: 5-7), or crossing pre-modern human history in Europe and America (Burns, 2007: 4). Therefore, it is very difficult to separate the story of human life with the culture of smoking with various rites and problems, because smoking is part of their cultural identity.

The presence of a fatwa on cigarettes issued by an ulama agreement under the banner of the Council of Indonesian Scholars (MUI) on January 26, 2009, in Padang Panjang, became a new episode in the cigarette debates with a long-established tradition in Indonesia. Although the fatwa provides forbidden prohibited laws, on March 6, 2010, the Majlis Tarjih and Tajdid (MTT) Muhammadiyah explicitly proclaimed haram absolutely. Long before some of the above issuance, the Islamic Association (PERSIS) on May 10, 1987, in Bandung, explicitly declared a makruh on smoking. This declaration becomes clear how the polarization of ulama in cigarette fatwa occurs in Indonesia. On the other sides, Nahdlatul Ulama is still determined that the law of smoking is between mubah, makruh, until haram, depending on illat (the cause of legal determination) of cigarettes. The winding road of the cigarette legal debate is closely related to how the process of fatwa production with various aspects of legal considerations, including the socio-anthropological aspects of Indonesian society.

In terms of Islamic law on the issue of cigarettes, the Indonesian Ulama Council (MUI) has a very strategic position on this issue, but instead of providing a solution to the debate, the MUI fatwa on cigarettes provides a new colour of discourse on cigarettes, because it turns out in the legal stipulation text, MUI stipulates the prohibited law against cigarettes, albeit limitedly. This is indicated by recommendations to the government and the House of Representatives (DPR) to make a law limiting the movement of the cigarette industry. Government Regulation (PP) No. 109 of 2012 concerning safeguarding material containing addictive substances in the form of tobacco for health, is not a coincidence, because besides adopting many Framework Convention on Tobacco Control (FCTC), it is also in harmony with the contents of the MUI Fatwa on cigarettes.

Even though formally the State of Indonesia is not an Islamic State, a fatwa is a form of 
a value system that in Muslim societies have legal authority in regulating social and religious life, as well as manifesting Islamic identity in a pluralistic society. In the realm of Islamic life, fatwas in several Muslim countries are even used as a reference point for norms that are adhered by all Muslims. A fatwa is not only a moral appeal but also has political and juridical instruments to be manifested by Muslims (Peterson, 1997). The dialectic between ideality and reality reasoning becomes an important issue in the matter of the determination of law (Arif, 2018) because on one side of the norm with its assertiveness presupposes the ideal order, while the flexible reality goes according to local logic and local wisdom.

In Indonesia, Fatwa can be used as an affirmation of ideological identity, even politically related to cigarette fatwa which is held as a source of legitimacy forbidding or halting cigarettes. Fatwa products are very close to the political, economic, and cultural interests of the communities where the fatwas are produced (Saifuddin, 2014: 33-52). Hence fatwa products are strongly influenced by how scholars as holders of religious authority relate to various institutions and social agents in society (Kaptein, 2004: 17). Therefore, the cigarette fatwa becomes more problematic when the dynamics of Islamic diversity in Indonesia are characterized by tensions between local Muslims who tend to be moderate with transnational Islam movement that tends to be radical (Wahid, 2009: 20), involved in the process of producing fatwa.

If the fatwa is considered as an arena of contestation between various agents and economical, political, cultural, ideological interests, where the position of the ulama in Indonesia as a holder of religious authority is? In detail, the formulation of the problems in this study is first, how does the fatwa as a representation of ulama negotiate with the political economy policies related to the cigarette industry in Indonesia? Second, how about cigarette fatwa, especially MUI fatwa as a representation of ulama negotiating with Islamic ideological agents in Indonesia is? Third, how does the cigarette fatwa accommodate the interests of the cigarette industry (entrepreneur) in Indonesia?

\section{Modalities and social practices in cigarette fatwas: a theoretical study}

The problems and dynamics in producing cigarette fatwa in Indonesia are one of the starting points for the fatwa being produced, and how the fatwa has implications for social, 
cultural and political life in a country. In a variety of literature, a fatwa was produced from phenomena in society. There is a relationship between both negotiation and contestation among various agents, structures, and social systems. In the fatwa literature, there are at least two important elements, namely problems that are emerged from social processes that are solved through the process of legal settlement (istifta) (Masoud, 2009: 341-66). The other part is the existence of ulama as the pruducer of fatwa (mufti), both personally and institutionally. The effectiveness of a fatwa depends greatly on how a fatwa is produced, and the extent of the mufti's capacity in the practice of the fatwa.

Sociologically, the capacity of the mufti, both personal and institutional has an important role in weighing the effectiveness of the fatwa, because, in the Islamic religious domain, the ulama is the authority holder. The religious authority possessed by the ulama will be more effective when it is supported by the practices and strategies of power that are united in that authority. In this case, the resources possessed by mufti become an important factor in the process of negotiation and contestation with various agents involved in the production of fatwas. The mufti resources are in the forms of charisma, Islamic scholarship, position in social structure, social networks, and community trust in the existence of mufti. In line with Pierre Bourdieu's view, that resources owned (capitals) Mufti is not always material (economic), but in many ways capital can be in the form of social, cultural, even symbolic capital (Bourdieu, 1998: 19-20).

By using Bourdieu's perspective, the practice of fatwa can be explained as well as other social practices where capitals (social, economic, cultural, symbolic) are operated in a field to be converted into dominant power (Bourdieu, 1998). In a more homogeneous field (champ), the capital is also contested in the context of a social disposition, which ultimately also dominates and mastery of discourse (Haryatmoko, 2016: 50). The existence of the Indonesian Ulema Council as a mufti in the fatwa of the cigarette, according to this perspective, plays its function as part of social agents contesting with other agents, including government agencies, cigarette industry owners, cigarette care communities that grow in the midst of society, and of course the plurality of cigarette fatwas issued by various Islamic social organizations in Indonesia.

Capital accumulation and maintaining the dominance of scholars in the contemporary 
Ijtihad: Jurnal Wacana Hukum Islam dan Kemanusiaan, Volume 20, No. 1, Juni 2020: 61-78

era are often carried out through ulama educational institutions. In addition to the institution of the cadre institution, the development of media technology has also become an important instrument in asserting the identity of the ulama and at the same time, its religious authority. The affirmation of the identity of the ulama was conveyed through religious opinions, both verbally and non- verbally, such as through the developing media (Zaman, 2010: 38-39).

The effectiveness of MUI's religious authority in this perspective is not only determined by the accumulation of various capital owned by ulama, but also determined by how the capital is converted into power that could dominate and influence people's behaviour in a certain time and place (Bourdieu, 1996: 125). The existence of social agents, as described above, forms new spaces where religious law $(f a t w a)$ is contested in the "religious public sphere" (Eickelman dan Anderson, 2003:1-2). In another views even Bourdieu, as understood by David Gartman, likens this social practice like a marketplace where the dominant group always distorts and reproduces capital by supplying lifestyles, meeting consumer demands to maintain its dominance (Gartman, 2002: 260).

It is in this assumption that the third dimension of the fatwa appears, in addition to the istifta and mufti, namely the implementation of the fatwa. In this dimension, the power of resources (capital) of the mufti is confronted with the social space (field), where social disposition and reposition are created, space where the process of dominating and being dominated is practised almost as natural, so that the compliance of fatwa seekers (mustafti) to the fatwa issued by the mufti, become the main choice. Not only that, but even the fatwa issued by the mufti-flowed to the rhythm is also created by dominant groups or social agents. Bourdieu called it as "habitus" (Bourdieu, 1998: 25).

The implementation of fatwa as a social practice can thus be explained by linking between social agents involved in fatwa production, managing their resources, and how they fight for dominance, so as to gain a dominant position, linked to the arena (field) where the fatwa was implemented. The assumption of this theory refers to the logic of social practice developed by Bourdieu that social practice is the relation between habitus, capital and arena (Bourdieu, 1996: 101). This social practice is methodologically traceable through examining the involvement of each social agent in the fatwa, the resources they own, and how these 
resources are operated in a particular social space.

By applying the literature study supported by some secondary data, this study at least found three important discourses that will be discussed in constructing and developing the concepts in this study, namely cigarette discourse in figh literature, discourse on developmentalism in Indonesia as the background of Government policy in controlling consumption tobacco, and fatwa discourse as a representation of scholars as holders of religious authority.

\section{Cigarette discourse in figh literature}

Two centuries after the discovery of the American continent by Christoper Colombus, where tobacco consumption was found, tobacco had only entered the Arab region through Sudan, which was around the 11th century Hijriyah. From Sudan then, it spread to the western (Magribi) and eastern (mashriqi) regions of the Arabian peninsula (Ibnu Al Shiddiq, 1985: 5-6). The entry of tobacco in the Arabian peninsula around the XI century Hijriyah shows that the emergence of tobacco or cigarettes legal occurred long after the Tashri ' era during the Umayyad dynasty, where Islamic law was discussed and codified according to the Islamic school of law (madhab) (Surjaman, 1991: vi-vii). It also shows that the law regarding tobacco products has not been explicitly discussed (sarib) in the main sources of Islamic law (Al-Qur'an and Sunnab).

The absence of a sarih source on cigarette law in the sources of Islamic teachings ( $\mathrm{Al}$ Qur'an and Sunnab) makes cigarette law a debate (ikhtilaf) among fiqh scholars. There are three legal provisions for cigarettes, namely mubah, haram, and makruh, each of which has its own reasons, both based on analogy (qiyas) with the naqli argument (dalil naqly) and based on consideration of the socio-cultural logic underlying it. For scholars who set unclean laws against cigarettes, there are four underlying reasons. First, health reasons are based on authoritative recommendations from medical experts. If indeed, the medical authorities say that smoking endangers the health, then the law of cigarettes is haram (Jampes, 2013: 09).

Quoted in the book of Hasyiyah Shaykh Syihabuddin Ahmad ibn Ahmad ibn Salamah al Qalyubi, an Islamic scholar from the Shafi'i school, that among the goods is not unclean, but should not be consumed (haram) is a cigarette because it can bring various diseases 
to the body and endanger health (Alqalyuby, 1956: 69). This opinion is also supported by Sheikh Ibrahim Al Laqani Al Maliki, that one of the items that cause loss of mind when it is consumed, is cigarettes. These two opinions provide answers which conclude that any food or drink that poses a danger to the health of the body and removes the mind, is forbidden to be consumed (haram), as conveyed by Sheikh Sulaiman ibn Muhammad ibn Umar Al Bujairamy (Al Bujairami, 1996: 233). The reason for removing mind is also the second reason why cigarettes are justifien as haram, based on the hadith from Umm Salamah that "The Messenger of Allah forbids consuming intoxicating foods or drinks and removes the mind based on the recommendations of health experts" (Jampes, 2013:10).

The third reason, which underlies the haram on cigarettes is because it smells unpleasant or disliked by many people. This law is based on qiyas about the smell of onions, both garlic and onion. The smell of someone who smokes is no better than the scent of onions which is a hadith is mentioned as one of the scents that are not liked by the Messenger of Allah. The fourth reason is that smoking results in economic waste. Among the opinions stating this reason is Shaykh Mahmud Shaltut in the book "Al-Fatawa", which states that "if the money spent to buy cigarettes is more useful and useful for other purposes then it is not permitted (adamu ibahatihi) to buy cigarettes and consume them" (Shaltut, 2001: 384).

If seen from the arguments built by the scholars who forbid smoking above, then it can be found two things that are a source of debate. First, the unlawful legal basis for cigarettes above uses the qiyas method, where the determination of the law is based on the common cause (illat) (Muhtarom, 2015: 03) between the main law (aşl) with the law of the case that came later ( far ${ }^{r}$ (Nashirudin, 2015: 21-26). The process of finding the similarity of illat to determine the law (ta'tlu al abkām) can be seen from the comparison between the smell of cigarettes and the smell of onions. The second argument, which was argued by the scholars who forbid smoking is a consideration of the purpose of the enactment of the law (maqüsid al shariah). This maslahah approach is seen as more flexible in responding to the evolving social dynamics. This can be analyzed in the fourth reason forbidding cigarettes in the book of Al Fatawa by Shaykh Mahmud Shaltut as described above.

The two arguments above open up opportunities to present other laws, besides illicit laws are on cigarettes, along with social dynamics, and socio-cultural conditions in various 
regions. Sheikh Abdul Hayyi ibn Muhammad Ibn Al Şidiq (Ibnu Al Shiddiq 1985) explains several things related to the cigarette law that tends to change. The main basis used to punish the mubah for cigarettes is the absence of an explicit argument about halal or haram for cigarettes. The scholars of the "Maghribi" region tend to impose unlawful laws on cigarettes, but the scholars of "Mashriqu" tend to justify smoking, even if women make cigarettes as part of their daily needs, husbands are obliged to give because it is part of their living.

The first explanation related to this argument is that if the reason is unlawful for cigarettes because smoking is an item that is harmful to health, then the argument is refuted by the fact that there are many active smokers who are actually healthy and live longer. If there is research which states that smoking is very dangerous for the health of the sample studied, then the methodological research cannot be applied in general. Second, goods dangerous to bodily health that result in being punished haram consists of two kinds, namely the danger of the substance of the item (li dhatihi) and the danger from arising from outside the item (li gairi dhatibi). Cigarettes are goods made from tobacco which are in substance a halal and clean plant, even if consumed by people in certain conditions can be dangerous. Even so the danger of cigarettes for people in a casuistic manner can not be used as an unlawful legal reason for cigarettes.

Similarly, M. Arfin Hamid (2017: 46-54) explained that "cigarette" is one thing, and "smoking" is a different thing, although it is interconnected. A cigarette is substantially mubah (li dhatihi), but smoking can be haram (li gairi dhatihi) when it is done by people who are vulnerable to cigarette smoke. This position forbids smoking as well as wine (khamr) being irrelevant.

The third explanation, related to the weak legal argumentation forbidden by cigarettes for reasons that it smells unpleasant or leads to dirty acts (kbaba'ith), is the qiyas method used to equate cigarettes with onions. Comparing cigarettes with onions that are considered dirty and smell according to Abdul Hayyi ibn Al Shiddiq is not quite right, because the Prophet Muhammad himself only hated the smell, and not forbid it. When the hadith came about the Prophet's dislike of the smell of onions, the Muslim community was busily forbidding the onions, but after the Prophet learned of the growing opinion, Rasulullah 
Ijtihad: Jurnal Wacana Hukum Islam dan Kemanusiaan, Volume 20, No. 1, Juni 2020: 61-78

asserted that "I should not forbid something that is halal by Allah, I just do not like the smell "(Ibnu Al Shiddiq, 1985: 56). Equating cigarettes with onions indirectly also punish cigarettes into mubah (li dhatihi).

One thing that is important to note is that dirty acts that lead to haram cannot be seen from one particular culture. It may be considered that cigarettes are something dirty by one community, but in other communities, smoking is considered not something dirty and disgusting. This is because the concept of clean and dirty is a part of cultural constructions, and is related to social structure (Douglas, 1966: viii). Hence according to this argument, the law of makruh against cigarettes becomes not absolute, if what is made causa (illat) is a dirty issue.

From the cigarette legal debates in the study of jurisprudence above, the law "cigarette" and "smoking", is strongly influenced by social facts where the fatwa was produced. The debates over the discourse thus developed, not just halal, haram, and makruh against cigarettes and smoking, but in the context of what kind of community the fatwa was applied. Therefore base on a sociological approach, especially related to economic, social and political structures, becomes very important. The relationship between sociological facts established Islamic legal norms, and political reality will significantly determine the effectiveness of a fatwa.

\section{Cigarettes in development policy in Indonesia}

In Indonesia, cigarettes have become an important part of people's lives. Since preindependence times, cigarettes have been used as friends in chatting, socializing, and even as a sweetener in intensive conversation to prepare the nation's pre-independence. After Indonesia's independence, cigarettes are also one of the dominant commodities in the wheels of Indonesia's economy. Entering the new order era, the momentum of the development of cigarettes is increasingly visible, supported by government policies and opportunities for industrialization in third world countries. Mark Hanusz noted that there were at least three crucial moments in the development of the cigarette industry in the new order era (Hanusz, 2011: 29). First, in the 1970s, the world oil price experienced a very significant increase as a result of the formation of a cartel of oil-exporting countries incorporated in OPEC. 
Indonesia, as an oil-producing country, also gets a "blessing" from the booming oil prices. The effect was the increase in the level of the Indonesian economy, which macro influence the economic growth rate of the country and political stability. This encourages countries in the world to begin to look at Indonesia as one of the third world countries to be reckoned with in the Southeast Asian region. In such a situation, many foreign investors entered Indonesia, then influenced the process of industrialization in various sectors. Slowly but surely, there will be a shift in the community's production system from the primary sector (agriculture) to the secondary sector (industry).

Second, the process of industrialization during the 1970s, was very influential on the growth of the cigarette industry in the country, especially on the island of Java. On this island, especially Central Java and East Java, cigarette factories have been established and produced cigarettes with mechanical power. The effect of the industrialization of cigarettes was that the quality and quantity of cigarette production was increasing. Cigarette products were not only able to play in the local market, but cigarette production in Indonesia was also able to compete internationally.

Third, the policy of the New Order government to promote transmigration made equity in all fields, not only in population distribution but also in the distribution of culture and cigarette consumption. At this moment, the cigarette market was widened and consumed not only in Java as a producer but has begun to spread to the transmigration destinations, such as Sumatra and Kalimantan, including in Eastern Indonesia.

More than two decades after the collapse of the current New Order regime, the cigarette industry is still an important part of the Indonesian economy. Kata Data News and Research (Data Box, 2017) issued data, and there has been an increase in cigarette excise revenue from year to year in the past seven years. It is explained that since 2010, the contribution of cigarette excise tax amounted to 63.3 trillion until 2017 it rose to 149.9 trillion, or an increase of $250 \%$ over the past seven years. This shows that the economic potential of tobacco excise and its derivatives is very potential in increasing the rate of national economic growth.

Seeing the great potential that exists in the cigarette industry, it is not surprising that the government cannot escape the dependence of the cigarette industry which contributes 
to the country's foreign exchange up to $10 \%$ of the state budget, fantastic value in the era of "development" policy. Developmentalism (development policy) is a system that is built on the ideas of European and American countries that are implemented in third world countries after World War II. This policy was taken to encourage economic, social, political and cultural underdevelopment in the countries of the former colonies or countries in the South, so that they could progress gradually (Shareia, 2015: 78). In this policy consideration of macroeconomic growth is highly considered by market players at the global economic level (Pereira, 2012: 347-66).

The effect of the application of development theories in various countries was that there was some progress in the economic field, especially industrialization, and at the same time a very varied negative impact (Escobar, 1995: 04). In Indonesia, also, to create gradual economic growth, it also raises extraordinary gaps due to the failure of the trickle-down effect expected from the policy (Wahid, 1999: 39). Hence, the criticism of development theory becomes very intensive carried out by social scientists who try to offer various theories that can break the deadlock.

The other proposals of the development theory are the concept of development not only developing economic sector, but also the humanitarian sector (Nussbaum dan Sen, 1993: 02). It is on this concept that smoking as one of the potential commodities in Indonesia becomes very problematic. On the one hand, smoking is one of the sources of foreign exchange, on the other hand, smoking is considered as one of the causes of the failure of quality human development because it is considered as a source of all degenerative diseases.

In addition to economic and cultural issues, smoking is also a serious conversation related to world health issues. In 2003 the WHO world health agency with several of its members signed a tobacco product control agreement. The agreement was then known as the Framework Convention on Tobacco Control (FCTC). Ten years later, in 2013, FCTC was ratified by 170 countries in the world, and Indonesia was the only country in Asia that had not ratified the convention. Again, the economic problem is one of the reasons because $95 \%$ of excise tax revenue comes from tobacco-derived products (cigarettes), as well as cultural issues. 
There are two problems faced by the Indonesian people in the reform era, related to this cigarette problem. First, the internal side of cigarettes has become part of the social history of the Indonesian people. Over all cigarettes also have a big role in the nation's economic development. Second, from the external side, there is international pressure that forces the entire nation to control tobacco consumption, either in the name of world health or economic-political interests.

In the end, the development theory will experience a face shift following the sociological and political conditions in each country. In the current Indonesian context, handling issues about smoking more often applies a post-development approach (Escobar, 1995). The issue of locality is an essential consideration in solving the problem of smoking which is also an international concern. Even though international pressure is so intense about limiting the consumption of tobacco products through the FCTC, Indonesia has not yet to ratify the convention. It is undoubtedly very problematic for the Indonesian government, because it is an economically very beneficial, medically very detrimental effect, and culturally there is much tension, especially related to religious ideologies that are now developing.

\section{Cigarette fatwa and religious authority in Indonesia.}

Cigarettes in terms of Indonesian Islamic civilization, have been an important issue since the country was not yet independent. Sheikh Ihsan Jampes in his book entitled "Irshädu al ikbwän fi bayani Shurbi al Qabwah wa al Dukbān" explains how the legal debate occurred among the scholars about the law of cigarettes (Jampes, 2013). With a rajaz rhythm, he gives a clever explanation of why he smokes cigarettes, from shabby, transformed, to illegal, with an anthropological, historical approach. Among the scholars who legalized cigarettes, there are mentioned by Abdul Ghani Al Nablisy in the book of Șulhu Baina al Ikhwàn fi Hukmi Ibähati al Dukhān, Imam Mahmud ibn Salamah al Radhi in the book Ta'yidu al I'lan bi Adami Tabrimi al Dukhan, and there are several scholars others. This classic book served as a source of legitimacy for traditional students in the treatment of cigarettes.

In the Indonesian Muslim community, the law on smoking is obvious. Majlis Ulama Indonesia (MUI) and Majlis Tarjih and Tajdid (MTT) Muhammadiyah tend to forbid smoking, although this does not necessarily reduce the number of cigarette consumers. 
Ijtihad: Jurnal Wacana Hukum Islam dan Kemanusiaan, Volume 20, No. 1, Juni 2020: 61-78

The real issue is not halal or haram, but how Islamic norms have a coercive value. This impression of coercive values is now an actual issue in ideological tensions in Indonesia, including the inclusion of normative Islamic (shar'i) views in positive law.

Fatwas are ethical practices which in the language of anthropology are born and developed along with social processes. The existence of ethics cannot be controlled and suppressed by anyone because ethics is built on authority agents that include natural processes (Agrama, 2010: 02-18). In practice, ethics that are practised in the form of fatwa are always controlled by institutionalized authorities. In this position, the fatwa becomes coercive and almost equalled the positive law. In the view of Hussein Ali Agrama, interpreting authority and legal institutions is a very problematic thing, because the authority which means competence that can be experienced naturally in social processes, is built in the power relations of authorized agents. Under these conditions, it is complicated to distinguish between legal institutions and equally coercive authorities.

In formal, fatwa institutions do not have coercive authority, and culturally, fatwas are still used as a source of legitimacy in Muslim societies. The debate about holders of religious authority, maintaining and preserving authority is very important to be discussed. In explaining religious scholars and authority in the contemporary era, Muhammad Qasim Zaman says that the religious authority possessed by ulama was built continuously through social processes, especially through the cadre institutions or educational institutions. In addition to the institution of the cadre institution, the development of media technology has also become an important instrument in affirming the religious identity and religious authority. The affirmation of religious identity is conveyed through religious opinions, both orally and in writing through developing media (Zaman, 2010: 56).

There are many problems when the Islamic public is not in the same ideology and has been polarized into various kinds of ideas. In Indonesia, religious authority cannot be addressed to a figure with a particular ideological label, especially if it is related to political issues or sensitive matters. Nico Kaptein's illustration in recording the fatwa in Indonesia clearly illustrates this problem. Kaptein also explains how religious authority was constructed through various religious instruments, symbols and religious identity (Kaptein, 2004: 1112). In this case, media technology is also an essential factor in constructing religious 
authority. It is at this stage that the fatwa on smoking becomes an arena of "fighting" to get religious authority because there are cultural agents or dominant structures that support the existence of the ulema as religious elites.

During the reign of the New Order, relations between ulama and the government (state) were built in a dominative pattern of relations where ulama institutions were formed to support government policies related to Islamic religious issues. In addition, the existence of institutionalized ulama makes government control through the structure of the ulema, which in the majority of Indonesian Islamic society, has a very strategic position. The emergence of the Indonesian Ulema Council (MUI) on July 26, 1975, which was formed by the New Order government was a political strategy of "corporatism" to control political movements based on Islam (Porter, 2002: 02). At this stage, the religious authority of the ulema cannot be released from power, either through political resources or through the production of religious discourse.

In the reform era, where ulema's polarization has been so massive, ulama institutions are no longer centred only on government-formed institutions supported by power, but also clerics born of the political process, as well as from the cultural process. These point discussions here brings an idea of how religious authority becomes an essential discourse in which scholars from various circles are involved. It is in this position that the practice of cigarette fatwa in Indonesia is placed, where the resources (modality) possessed by ulemas as religious authority holders have an important role in producing effective fatwas.

\section{Conclusion}

As a final illustration of this paper, an important point that should be underlined is the emergence of cigarette fatwa in Indonesia, not suddenly, and even stopping, but there is a complicated discourse, how the fatwa is produced, and how the fatwa product is negotiated in the social realm. The fatwa about smoking, haram, halal, or makrub, is still developing along with the dynamics of discourse battle in the arena of Indonesian people's life.

Ulama as the authorized holder of the fatwa is undoubtedly not only the social agent producing discourse to enact their fatwa, but the ulama will face policies adopted by the state in managing social, economic and political resources. On other sides, the effectiveness of 
ljtihad: Jurnal Wacana Hukum Islam dan Kemanusiaan, Volume 20, No. 1, Juni 2020: 61-78

the control of power held by the fatwa must also clash with the economic capital owned by cigarette manufacturers. The crucial thing is how scholars as social agents solve the identity problem that is always inherent in their bodies.

Ulama as fatwa producers inevitably has to deal with the power and political capital of development policies in Indonesia. Ulema should also intersect with the culture that frames them, the discourse they produce, and of course, cultures that come from outside or transnational. In this position, the modality of the ulema was negotiated and contested in the arena of the practice of fatwa on cigarettes.

\section{Bibliography}

Agrama, Hussein Ali. "Ethics, Tradition, Authority: Toward an Anthropology of the Fatwa." American Ethnologist 37(1) 2010: 2-18.

Arif, Firman Muhammad. "Dialektika Nalar Idealitas dan Nalar Realitas: Aplikasi Konsep 'Umum al-Balwa.' Ijtihad: Jurnal Wacana Hukum Islam dan Kemanusiaan Vol. 18, No. 1 (2018): 99-118.

Bourdieu, Pierre. Distinction, A Social Critique of the Judgement of Taste. viii. Cambridge Massachussets: Harvard Uneversity Press, 1996.

Bourdieu, Pierre. Practical Reason on the Theory of Action. Stanford California: Stanford University Press, 1998.

Brandt, Allan M. Cigarette Century, the Rise, Fall, and Deadly Persistence of the Product that Defined America. New York: Basic Book, 2007.

Al-Bujairami, Sulaiman ibn Muhammad ibn Umar. al-Bujairami alā al-Khathïb, Tukhfatu alHabìb alā Sharhi al-Khathỉb (al-Iqnā fi Halli al-fadhi Abi Shuja'). Bairut: Daar al-Kutub al-Ilmiyah, 1996.

Burns, Eric. The Smoke of the God, A Social History of Tobacco. Philadelphia: Temple University Press, 2007.

Data Box.. "Berapa Pendapatan Pemerintah dari Cukai Rokok? - Databoks.” 2017.Diambil 25 Januari 2018 (https://databoks.katadata.co.id/datapublish/2017/03/24/berapapendapatan-pemerintah-dari-cukai-rokok).

Douglas, Mary. Purity and Danger, an analysis of the Concepts of Pollution and Taboo. London; New York: Routledge, 1966. 
Cigarette fatwas, contestation of religious authority and politics in Indonesia (Saifuddin)

Eickelman, Dale F., dan Jon W. Anderson. New Media in the Muslim World, Second Edition: The Emerging Public Sphere (Indiana Series in Middle East Studies). Indiana University Press, 2003.

Escobar, Arturo. Encountering Development, the Making and unmaking of the third World. Princeton New Jersey: Princeton University Press, 1995.

Gartman, David. "Bourdieu's Theory of Cultural Change: Explication, Application, Critique." Sociological Theory, American Sociological Association 20-2 Juli 2002.

Hamid, M. Arfin. "Reinterpretation of Contemporary Islamic Law (Analysis Study of the Legal Fatwa of Smoking)." Journal of Law, Policy and Globalization Vol.61, 2017:46-54.

Hanusz, Mark. Kretek, the Culture and Haritage of Indonesia's Clove Cigarettes. Singapore: Equinox Publishing, 2011.

Haryatmoko. Membongkar Rezim Kepastian Pemikiran Kritis Post-strukturalis. Yogyakarta: Kanisius, 2016.

Ibnu al-Shiddiq, Abdu Al Hayyi Ibnu Muhammad. Hukmu al-Dukhan Wa Thabah. Mesir: Daar al-Bayan, 1985.

Jampes, Ahsan ibnu Dahlan. Irsyadu al-Ikhwan fi bayani abkami syurbi al-Qahwati wa al-Dukhan. Kediri: Ma’had al Islami An Nur As Salafi, 2013.

Kaptein, Nico JG. "The Voice of the 'Ulamâ': Fatwas and Religious Authority in Indonesia." Archives de sciences sociales des religions vol.125 Januari-Mart 2004 (Religious Authority In Indonesia):115-30.

Masoud, Muhammad Khalid. “The Significance of Istifta' in the Fatwa Discourse*.” Islamic Studies Vol. 48:3 2009 (03): 341-66.

Muhtarom, Ali. "Meninjau Ulang Teori Qiyas (Kajian Terhadap Illat Dalam Qiyas dan Upaya Pengembangan Teori Hukum Islam).” Jurnal Al Ahwal Vol. 7, No. 1 April 2015:1-22.

Nashirudin, Muh. "Ta'lil al-Ahkam dan Pembaruan Ushul Fikih.” Jurnal Abkam Vol. XV, No. 1, Januari 2015: 21-26.

Nussbaum, Martha, dan Amartya K. (Ed) Sen. The Quality of Life (Wider Studies in Development Economics). Oxford: Clarendon Press, 1993. 
ljtihad: Jurnal Wacana Hukum Islam dan Kemanusiaan, Volume 20, No. 1, Juni 2020: 61-78

Pereira, Luiz Carlos Bresser-. "Structuralist macroeconomics and the new developmentalism.” Brazilian Journal of Political Economy 32 No.02 Juli September 2012. Peterson, Jacob Skovgaard. "Defining Islam for The Egyptian State, Muftis and Fatwas of The Dar al-Ifta." Social, Economic, and Political Studies of The Middle East and Asia 59 Tahun 1997. t.th.

Porter, Donald J. Managing Politics and Islam in Indonesia. London: Routledge Curzon, 2002. Al-Qalyuby, Shihabuddin Ahmad ibnu Ahamad ibn Salamah. Hasyiyah ala Syarbi Jalalu alDin Muhammad Abmad al-Mahalli ala Minhaju al-Thalibin. III. Mesir: Musthafa al- Babi Al Halaby Press, 1956.

Saifuddin. "Dinamika Otoritas Kharismatik Kiai dalam Proses Politik." Kasyf el Fiker 1, Nomor 1, J uni 2014:33-52.

Shaltut, Mahmud. Alfatwa, Dirasat Limusykilaati al-Muslimi al-Muashiri fi Hayatibi al- Yaumiyyati wa al-aammati. XVIII. Bairut: Daar al-Syuruq, 2001.

Shareia, Bubaker F. "Theories of Development." International Journal of Language and Linguistics Vol. 2, No. 1; March 2015.

Surjaman, Tjun, ed. Hukum Islam di Indonesia, Pemikiran dan Praktek. Bandung: Remaja Rosda Karya, 1991.

Wahid, Abdurrahman (ed). Ilusi Negara Islam, Ekspansi Gerakan Islam Transnasional di Indonesia. Jakarta: The Wahid Institute, 2009.

Wahid, H. Telikungan kapitalisme global dalam sejarah kebangsaan Indonesia. FK-GMNU, 1999.

Zaman, Muhammad Qasim. The Ulama in Contemporary Islam: Custodians of Change. Princeton University Press, 2010. 